\title{
Loss of Kainate Receptor-Mediated Heterosynaptic Facilitation of Mossy-Fiber Synapses in KA2 ${ }^{-/-}$Mice
}

\author{
Anis Contractor, ${ }^{1}$ Andreas W. Sailer, ${ }^{1}$ Melanie Darstein, ${ }^{1}$ Cornelia Maron, ${ }^{1}$ Jian $\mathrm{Xu},{ }^{1}$ Geoffrey T. Swanson, ${ }^{2}$ and \\ Stephen F. Heinemann ${ }^{1}$ \\ ${ }^{1}$ Molecular Neurobiology Laboratory, The Salk Institute for Biological Studies, La Jolla, California 92037, and ${ }^{2}$ Department of Pharmacology and \\ Toxicology, University of Texas Medical Branch, Galveston, Texas 77555-1031
}

Multimeric assemblies of kainate (KA) receptor subunits form glutamate-gated ion channels that mediate EPSCs and function as presynaptic modulators of neurotransmitter release at some central synapses. The KA2 subunit is a likely constituent of many neuronal kainate receptors, because it is widely expressed in most neurons in the CNS. We have studied the effect of genetic ablation of this receptor subunit on synaptic transmission at the mossy-fiber-CA3 pyramidal cell synapse in hippocampal slices, where kainate receptors are localized to both presynaptic and postsynaptic sites. We found that both postsynaptic and presynaptic mossy-fiber kainate receptor function is altered in neurons from $\mathrm{KA}^{-l-}$ mice. The presynaptic facilitatory autoreceptor, which modulates glutamate release from mossy-fiber terminals, had a reduced affinity for exogenous agonists and synaptic glutamate. Although presynaptic facilitation attributable to homosynaptic glutamate release was normal at mossy-fiber synapses in $\mathrm{KA}^{-1-}$ neurons, heterosynaptic kainate receptormediated facilitation resulting from the spillover of glutamate from CA3 collateral synapses was absent. Consistent with a decrease in glutamate affinity of the receptor, the half-decay of the postsynaptic kainate-mediated EPSC was shorter in the knock-out mice. These results identify the KA2 subunit as a determinant of kainate receptor function at presynaptic and postsynaptic mossy-fiber kainate receptors.

Key words: KA2 kainate receptor subunit; knock-out mice; presynaptic kainate receptors; CA3 pyramidal neurons; hippocampus; mossy-fiber

\section{Introduction}

Neuronal kainate (KA) receptor function has been studied most extensively in the hippocampus. These inotropic receptors are formed from heteromeric combinations of five individual subunits: the low-affinity subunits glutamate receptor 5 (GluR5), GluR6, and GluR7 form functional homomeric glutamate receptors, whereas the high-affinity subunits KA1 and KA2 do not function as homomeric receptors. When expressed with the lowaffinity subunits, KA1 and KA2 can coassemble and alter kainate receptor functional properties (Herb et al., 1992; Lomeli et al., 1992; Schiffer et al., 1997). Each of these receptor subunits is expressed at different levels in the principal neurons of the hippocampus, but only the KA2 subunit shows a nearly ubiquitous expression (Bahn et al., 1994; Bureau et al., 1999).

Kainate receptors are present either presynaptically or postsynaptically at a number of distinct hippocampal synapses (Kullmann, 2001), although only at mossy-fiber synapses, formed between the axons of dentate gyrus granule cells and

Received Aug. 28, 2002; revised 0ct. 31, 2002; accepted Nov. 5, 2002.

This work was supported by grants from the National Institute of Mental Health to A.C., the Schweizerische Nationalfond and the Deutsche Forschungsgemeinschaft to A.W.S., the National Alliance for Research on Schizophrenia and Depression (M.D., G.T.S.), and National Institute of Neurological Disorders and Stroke (G.T.S., S.F.H.). We thank Stephen $0^{\prime}$ Gorman for help with embryonic stem cell culture, The Salk Transgenic Core Facility for performing blastocyst injections, and Stacie Peters and Lora $0^{\prime}$ Leary for help with animal husbandry. We also thank Christophe Mulle for early discussions and for providing some of the mouse genomic clones.

Correspondence should be addressed to Dr. Anis Contractor, Molecular Neurobiology Laboratory, The Salk Institute for Biological Studies, 10010 North Torrey Pines Road, La Jolla, CA 92037. E-mail: contractor@salk.edu.

A. W. Sailer's present address: Merck \& Company, Inc., 126 East Lincoln Avenue, Rahway, NJ 07065.

Copyright $\odot 2003$ Society for Neuroscience $\quad 0270-6474 / 03 / 230422-08 \$ 15.00 / 0$ thorny excrescences of CA3 pyramidal neurons, are they found on both sides of the same synapse. Postsynaptic mossy-fiber kainate receptors mediate a small component of the EPSC (Castillo et al., 1997; Vignes and Collingridge, 1997). This current has slow rise and decay kinetics, which is inconsistent with the biophysical properties of kainate receptors described in recombinant expression systems (Dingledine et al., 1999). The kainate-mediated EPSC $\left(\right.$ EPSC $\left._{\mathrm{KA}}\right)$ is not altered in mice in which the GluR5 gene has been deleted (A. Contractor, unpublished observations); however, it is completely absent in GluR6 ${ }^{-1-}$ mice (Mulle et al., 1998), demonstrating that the critical subunit comprising these receptors is GluR6.

Presynaptic kainate receptors on mossy-fiber axons and boutons modulate glutamate release (Schmitz et al., 2001b). The application of very low concentrations of kainate facilitates the release of glutamate (Schmitz et al., 2001a), whereas the application of higher concentrations depresses release (Contractor et al., 2000; Kamiya and Ozawa, 2000; Schmitz et al., 2000), because of a depolarizing block of axonal conduction (Kamiya and Ozawa, 2000); this depression is absent in the GluR6 ${ }^{-1-}$ mice (Contractor et al., 2000). Presynaptic kainate receptors can also be activated by endogenous glutamate. Homosynaptic glutamate release from mossy-fiber terminals activates presynaptic kainate receptors, which contribute to the marked frequency facilitation of transmission observed during increased rates of stimulation (Contractor et al., 2001; Lauri et al., 2001). In addition, mossyfiber transmission can be modulated by kainate receptor activation resulting from the heterosynaptic spillover of glutamate from neighboring mossy-fiber inputs, as well as from the collat- 
eral synapses formed by the axons of other CA3 pyramidal neurons (Schmitz et al., 2000, 2001a). The apparent bidirectional nature of the response to the activation of presynaptic kainate receptors by exogenous agonists can be reproduced using different intensities of conditioning stimuli to initiate heterosynaptic glutamate spillover (Schmitz et al., 2001a). Because the GluR6 subunit is highly expressed in dentate gyrus granule cells (Bureau et al., 1999), and at least some of these effects are absent in GluR6 $^{-1-}$ mice (Contractor et al., 2000), it is thought that, similar to the postsynaptic kainate receptor, the GluR6 receptor subunit is the predominant and critical subunit for the function of presynaptic kainate receptors at mossy-fiber synapses. However, using compounds reported to have selective activity on GluR5containing kainate receptors, several studies suggest that receptors containing the GluR5 subunit are expressed at both postsynaptic (Bortolotto et al., 1999) and presynaptic sites of the mossy-fiber synapse (Lauri et al., 2001), in apparent contradiction to the findings in knock-out mice and the reported distribution of kainate receptors (Bahn et al., 1994; Bureau et al., 1999).

The KA2 subunit is also expressed in both granule cells and CA3 pyramidal neurons (Bureau et al., 1999) and might assemble with the GluR6 subunit to form heteromeric kainate receptors. Because pharmacological agents that specifically target KA2containing receptors are not available, we have analyzed the contribution of this subunit to kainate receptor function using genetargeted mice lacking the KA2 subunit. In this study, we focus on the physiological characterization of KA2-containing kainate receptors at mossy-fiber synapses. We demonstrate that both presynaptic and postsynaptic receptors are functionally intact in the $\mathrm{KA}^{-1-}$ mice; however, kainate receptor-mediated heterosynaptic facilitation of mossy-fiber EPSCs was not observed in these mice, likely reflecting a change in the agonist affinity of the presynaptic autoreceptor. Consistent with a decrease in the glutamate affinity of synaptic kainate receptors in these mice, the postsynaptic $\mathrm{EPSC}_{\mathrm{KA}}$ had faster current decay kinetics compared with wild-type mice. These results demonstrate that the KA2 subunit contributes to functional kainate receptors on both sides of the mossy-fiber synapse.

\section{Materials and Methods}

Generation of $\mathrm{KA}^{-/-}$mice. The mouse KA2 gene was disrupted by insertion of a phosphoglycerate-kinase-neomycin cassette (pgk-neo) by homologous recombination, replacing $1.3 \mathrm{~kb}$ containing two exons and a partial third exon that encode membrane domains I and II (see Fig. $1 \mathrm{~A}$ ). The final targeting construct contained 3.0 and $2.3 \mathrm{~kb}$ of homologous sequence $5^{\prime}$ and $3^{\prime}$, respectively, to the neomycin resistance marker. In addition, the targeting vector also contained a thymidine kinase (TK) gene under the control of the phosphoglycerate-kinase (pgk-TK) promoter to counterselect for nonhomologous integration (Mansour et al., 1988) (see Fig. 1A). Embryonic stem (ES) cell culture and electroporation techniques were as described previously (Sailer et al., 1999). Disruption of the KA2 gene was confirmed by Southern blotting using genomic DNA. We found 8 of 90 clones positive for the predicted homologous recombination event. Six clones were injected into blastocysts and implanted into foster mothers that gave birth to chimeric animals. Two chimeric mice transmitted the mutant allele through the germline to their offspring as judged by Southern blot analysis of the KA2 genomic locus using mouse genomic tail DNA (Laird et al., 1991). Subsequent intercrossing of heterozygous mice yielded $\mathrm{KA} 2^{-1-}$ mice at a Mendelian ratio of $22.7 \%(n=172)$. After transmission of the mutant allele in a mixed background (129SvEv/C57BL/6), we also generated an isogenic $\mathrm{KA} 2^{-1-}$ strain by breeding a chimera directly to $129 \mathrm{SvEv}$ wild-type animals. Animals from this $\mathrm{KA}^{-1-} 129 \mathrm{SvEv}$ strain were used for all subsequent experiments.

Generation of KA2 antibody and immunohistochemistry. A rabbit poly- clonal antibody was raised against the purified synthetic peptide SPPRPRPGPTGPRELTEHE, corresponding to the C-terminal 19 aa of the rat KA2 receptor subunit. A cysteine residue was added at the $\mathrm{N}$ terminus to facilitate conjugation to the carrier protein KLH. Peptide synthesis, rabbit immunization, serum collection from rabbits, and subsequent affinity purification of the crude serum against the immobilized immunizing peptide were performed by Bethyl Laboratories Inc. (Montgomery, TX). For immunohistochemistry, adult mice were transcardially perfused with $4 \%$ paraformaldehyde; the brains were removed, cryoprotected in $20 \%$ sucrose in PBS, frozen, and cut into $30-\mu \mathrm{m}$-thick sagittal sections. Sections were washed in PBS, blocked in PBS solution of 5\% goat serum and $0.1 \%$ Triton X-100, and incubated with anti-KA2 antibody in PBS-containing goat serum and $0.1 \%$ Triton X-100. The tissue was washed and incubated with biotinylated goat anti-rabbit secondary antibody (Vector Laboratories, Burlingame, CA), followed by incubation with an ABC elite kit (Vector Laboratories) and subsequent visualization with peroxidase-reduced diaminobenzidine (Sigma, St. Louis, MO).

Membrane preparation and Western blots. Plasma membranes were prepared from the brain tissue of wild-type and $\mathrm{KA} 22^{-1-}$ mice. Dissected hippocampi were homogenized in 10 vol of ice-cold buffer containing 10 $\mathrm{mm}$ Tris, $\mathrm{pH} 7.4,320 \mathrm{~mm}$ sucrose, and a mix of protease inhibitors containing $1 \mu \mathrm{g} / \mathrm{ml}$ leupeptin, $1 \mu \mathrm{g} / \mathrm{ml}$ pepstatin, and $2.5 \mu \mathrm{g} / \mathrm{ml}$ aprotinin. After centrifugation at $3000 \times g$ for $5 \mathrm{~min}$ at $4^{\circ} \mathrm{C}$, the supernatant was recovered and additionally centrifuged at $30,000 \times \mathrm{g}$ for $30 \mathrm{~min}$ at $4^{\circ} \mathrm{C}$. The pellet was resuspended in $50 \mathrm{~mm}$ Tris buffer, $\mathrm{pH} 7.4$, containing $1 \%$ Triton X-100 and protease inhibitors. Lysates were heated at $70^{\circ} \mathrm{C}$ in SDS sample buffer for analysis by electrophoresis and immunoblotting. For immunoprecipitation experiments, hippocampal membranes were incubated with polyclonal anti-R6/7 antibody (Upstate Biotechnology, Lake Placid, NY) for $2 \mathrm{hr}$, followed by incubation with protein A Sepharose for $45 \mathrm{~min}$ at $4^{\circ} \mathrm{C}$. The beads were then washed three times with 50 mu Tris, pH 7.4, containing 0.1\% Triton X-100. Samples were analyzed by electrophoresis and immunoblotting after heating at $70^{\circ} \mathrm{C}$ in SDS sample buffer.

Slice preparation and electrophysiology. Transverse hippocampal slices $(350 \mu \mathrm{m})$ were made from postnatal day 12 (P12) to P24 knock-out (isogenic 129SvEv) and wild-type (strain 129SvEv) mice. Animals were anesthetized with isoflurane and decapitated. Brains were removed under ice-cold sucrose slicing artificial CSF (ACSF) containing (in mM): 85 $\mathrm{NaCl}, 2.5 \mathrm{KCl}, 1.25 \mathrm{NaH}_{2} \mathrm{PO}_{4}, 25 \mathrm{NaHCO}_{3}, 25$ glucose, 75 sucrose, 0.5 $\mathrm{CaCl}_{2}$, and $4 \mathrm{MgCl}_{2}$, equilibrated with $95 \% \mathrm{O}_{2}$ and $5 \% \mathrm{CO}_{2}$. Slices were incubated at $28^{\circ} \mathrm{C}$ for $30 \mathrm{~min}$. Then the sucrose slicing solution was exchanged for a normal ACSF containing (in mM): $125 \mathrm{NaCl}, 2.4 \mathrm{KCl}, 1.2$ $\mathrm{NaH}_{2} \mathrm{PO}_{4}, 25 \mathrm{NaHCO}_{3}, 25$ glucose, $1 \mathrm{CaCl}_{2}$, and $2 \mathrm{MgCl}_{2}$. A $10 \mu \mathrm{M}$ concentration of D,L-APV and $100 \mu \mathrm{M}$ kynurenate were included in the slicing and incubation solutions. After the slices were transferred to a recording chamber, they were continuously perfused with ACSF containing $2 \mathrm{mM} \mathrm{CaCl}_{2}$ and $1 \mathrm{mM} \mathrm{MgCl}_{2}$. Whole-cell patch-clamp recordings were made from visually identified pyramidal cells in the CA3 region of the hippocampus at room temperature. Glass electrodes were pulled from borosilicate glass and had resistances of 3.5-4 M $\Omega$ when filled with internal solution containing (in mM): $95 \mathrm{CsF}, 25 \mathrm{CsCl}, 10 \mathrm{Cs}$-HEPES, 10 Cs-EGTA, $2 \mathrm{NaCl}, 2 \mathrm{Mg}$-ATP, 10 lidocaine $\mathrm{N}$-ethylbromide, 5 TEA-Cl, and 54 - $\mathrm{AP}, \mathrm{pH}$ adjusted to 7.3 with $\mathrm{CsOH}$.

Synaptic currents were evoked with monopolar glass electrodes positioned in the stratum lucidum for mossy-fiber stimulation and in the stratum radiatum to activate collateral inputs. Data collection and analysis were done with pClamp 8 software (Axon Instruments, Foster City, CA). To isolate mixed AMPA/kainate receptor-mediated EPSCs, slices were bathed in ACSF with $10 \mu \mathrm{M}$ bicuculline, $50 \mu \mathrm{M}$ picrotoxin and 50 $\mu \mathrm{M}$ D-AP-5; to isolate the EPSC $_{\mathrm{KA}}, 100 \mu \mathrm{M}$ GYKI53655 was added to the ACSF. Mossy-fiber EPSCs were distinguished by their characteristically large paired-pulse facilitation (Salin et al., 1996), rapid rise time, and short latency (Yeckel et al., 1999), and by the inhibition of transmission by the group II metabotropic GluR (mGluR) agonist L-carboxycyclopropylglycine (L-CCG-1) (10 $\mu \mathrm{M})$ (Kamiya et al., 1996), which was applied at the end of each experiment. Recordings in which there was $>70 \%$ inhibition of the EPSC were included in the analysis. Data are presented as means \pm SEM. Parameters were compared using Student's 
unpaired $t$ test (where not stated), the Kolmogorov-Smirnov test, and one-way ANOVA; $p<0.05$ was considered significant.

\section{Results \\ Generation and molecular characterization of $\mathrm{KA}^{-1-}$ mutant mice}

To study the role of the KA2 receptor subunit in hippocampal synaptic transmission, we generated KA2 knock-out mice. We constructed a targeting vector in which a $1.3 \mathrm{~kb}$ section of the KA2 gene, which included the exons coding for the membrane domains I and II, was replaced by a neomycin-resistant marker cassette (Fig. 1A). Standard techniques were used to electroporate ES cells, and homologous recombination of the targeting construct was confirmed by Southern blot. Six positive clones were injected into blastocysts to generate chimeric animals. Intercrossing the heterozygous offspring produced $\mathrm{KA} 2^{-1-}$ mice, which were then backcrossed to $129 \mathrm{SvEv}$ mice to produce the $\mathrm{KA} 2^{-/-}$isogenic strain. These mice were used for all experiments described in this report.

We confirmed that the mutant mice lacked the KA2 subunit using an antibody raised against the $\mathrm{C}$ terminal of the protein. Immunoblot analysis of the $\mathrm{KA} 2^{-/-}$mice demonstrated that KA2 protein was absent, whereas immunoreactivity for the GluR6/7 proteins was not grossly different (Fig. 1 B). Similarly, hippocampal sections from $\mathrm{KA}^{-/-}$mice were not immunoreactive with the anti-KA2 antibody, whereas in wild-type mice we observed prominent labeling of the stratum lucidum and pyramidal cell layers of CA3 and CA2 subfields, confirming previous results with a distinct anti-KA2 antibody (Petralia et al., 1994) (Fig. $1 C$ ). $\mathrm{KA}^{-1-}$ mice did not differ from their littermates in breeding or general health status and did not exhibit any gross abnormalities in behavior.

Presynaptic kainate receptor response to low concentrations of kainate is impaired in $\mathrm{KA}^{-/-}$mice

Exogenous activation of presynaptic mossy-fiber kainate receptors with high concentrations of kainate (500 nM) depresses excitatory transmission by causing a depolarizing block of axons (Kamiya and Ozawa, 2000), whereas a low concentration of kainate $(50 \mathrm{~nm})$ facilitates transmission by inactivating potassium channels and augmenting the presynaptic action potential (Schmitz et al., 2001a). To test whether the bidirectional modulation of transmission is altered in mice lacking the KA2 subunit, we recorded EPSCs arising from the activation of mossy-fiber AMPA and kainate receptors $\left(\mathrm{EPSC}_{\mathrm{AMPA} / \mathrm{KA}}\right)$ in $\mathrm{CA} 3$ neurons while applying kainate to hippocampal slices from wild-type and $\mathrm{KA} 2^{-1-}$ mice. The application of $50 \mathrm{~nm}$ kainate to slices from wild-type mice caused a significant facilitation in the amplitude of EPSC ${ }_{\mathrm{AMPA} / \mathrm{KA}}$ compared with basal transmission (130 $\pm 13 \%$; $n=6$; $p<0.05$; one-way ANOVA) (Fig. $2 A, E$ ). In recordings from $\mathrm{KA}^{-1-}$ mice, the application of $50 \mathrm{~nm}$ kainate did not significantly alter $\mathrm{EPSC}_{\mathrm{AMPA} / \mathrm{KA}}$ amplitudes $(97 \pm 7.3 \%$ of control amplitude; $n=7 ; p>0.05$; one-way ANOVA) (Fig. 2C,E).

Mossy-fiber EPSCs are depressed by the application of higher concentrations of kainate (Contractor et al., 2000; Kamiya and Ozawa, 2000; Schmitz et al., 2000). Bath application of $500 \mathrm{nM}$ kainate resulted in a significant depression of the $\mathrm{EPSC}_{\mathrm{AMPA} / \mathrm{KA}}$ in slices from wild-type mice ( $50 \pm 9.2 \%$ of control EPSC; $n=4$; $p<0.05$; one-way ANOVA) (Fig. $2 B, E$ ). In slices from KA2 ${ }^{-1-}$ mice, $500 \mathrm{~nm}$ kainate also caused a significant depression of the mossy-fiber evoked EPSC $(65 \pm 7.3 \% ; n=5$ of the control EPSC; $p<0.05$; one-way ANOVA) (Fig. $2 D, E$ ). We also measured the effect of intermediate concentrations of kainate (100 and $250 \mathrm{nM}$ )
A

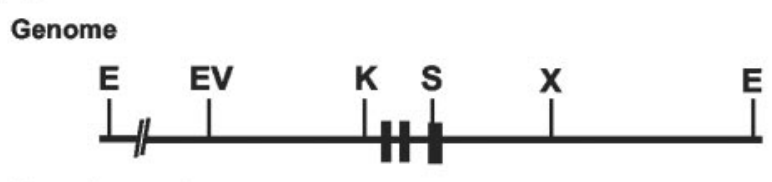

Targeting vector

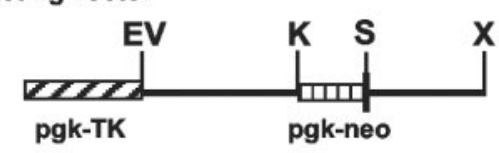

Targeted allele

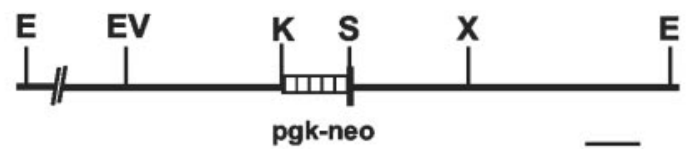

$\overline{1 \mathrm{~kb}}$
Wildtype KA2\%

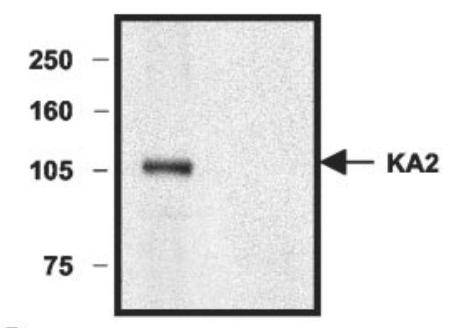

C

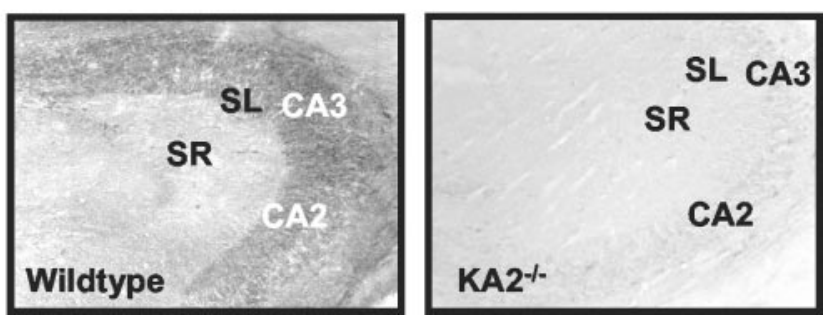

Figure 1. Generation and characterization of KA2 receptor subunit-deficient mice. A, top, Genomic map of the mouse KA2 locus around the exons (black boxes) coding for the transmembrane domains I and II. Middle, The targeting vector containing a neomycin resistance marker under the control of pgk-neo. The hatched box (pgk-TK) denotes a thymidine kinase domain of the targeting vector used for counterselection against nonhomologous integration. Bottom, An illustration of the KA2 locus after homologous recombination. E, EcoRl; EV, EcoRV; K, Kpnl; S, Sacll; $X, X b a l . B$, Immunoblot analysis of membrane proteins from hippocampi of wild-type and $\mathrm{KA}^{-1-}$ mutant mice using an anti-KA-2 antibody and anti-GluR6/7 antibody. C, Immunohistochemical analysis of $\mathrm{KA2}^{-1-}$ mice. Hippocampal sections from wild-type and $\mathrm{KA2}^{-1-}$ mice were immunostained with anti-KA2 antibodies. Staining was seen in the stratum lucidum (SL) and pyramidal cell layers of the $C A 3$ and $C A 2$ but not in the stratum radiatum $(S R)$ in sections from wild-type mice (left). No staining was observed in any region in hippocampal sections from $\mathrm{KA}^{-1-}$ mice (right).

on $\mathrm{EPSC}_{\mathrm{AMPA} / \mathrm{KA}}$. The application of $100 \mathrm{~nm}$ kainate did not significantly affect $\mathrm{EPSC}_{\mathrm{AMPA} / \mathrm{KA}}$ in wild-type mice $(110 \pm 4.6 \%$; $n=3 ; p>0.05$; one-way ANOVA); however, this concentration significantly depressed $\mathrm{EPSC}_{\mathrm{AMPA} / \mathrm{KA}}$ amplitudes in $\mathrm{KA}^{-1-}$ mice $(88 \pm 9.2 \% ; n=6 ; p<0.05$; one-way ANOVA) (Fig. $2 E)$. In contrast, the application of $250 \mathrm{~nm}$ kainate caused a significant depression of EPSC $_{\mathrm{AMPA} / \mathrm{KA}}$ in both wild-type recordings (88 \pm $10 \% ; n=6 ; p<0.05$; one-way ANOVA) and $\mathrm{KA}^{-1-}$ recordings $(78 \pm 5.9 \% ; n=4 ; p<0.05$; one-way ANOVA) (Fig. $2 E)$. The application of each of these concentrations of kainate did not alter $\mathrm{EPSC}_{\mathrm{AMPA} / \mathrm{KA}}$ in slices from GluR6 ${ }^{-1-}$ mice (Fig. $2 E$ ). 


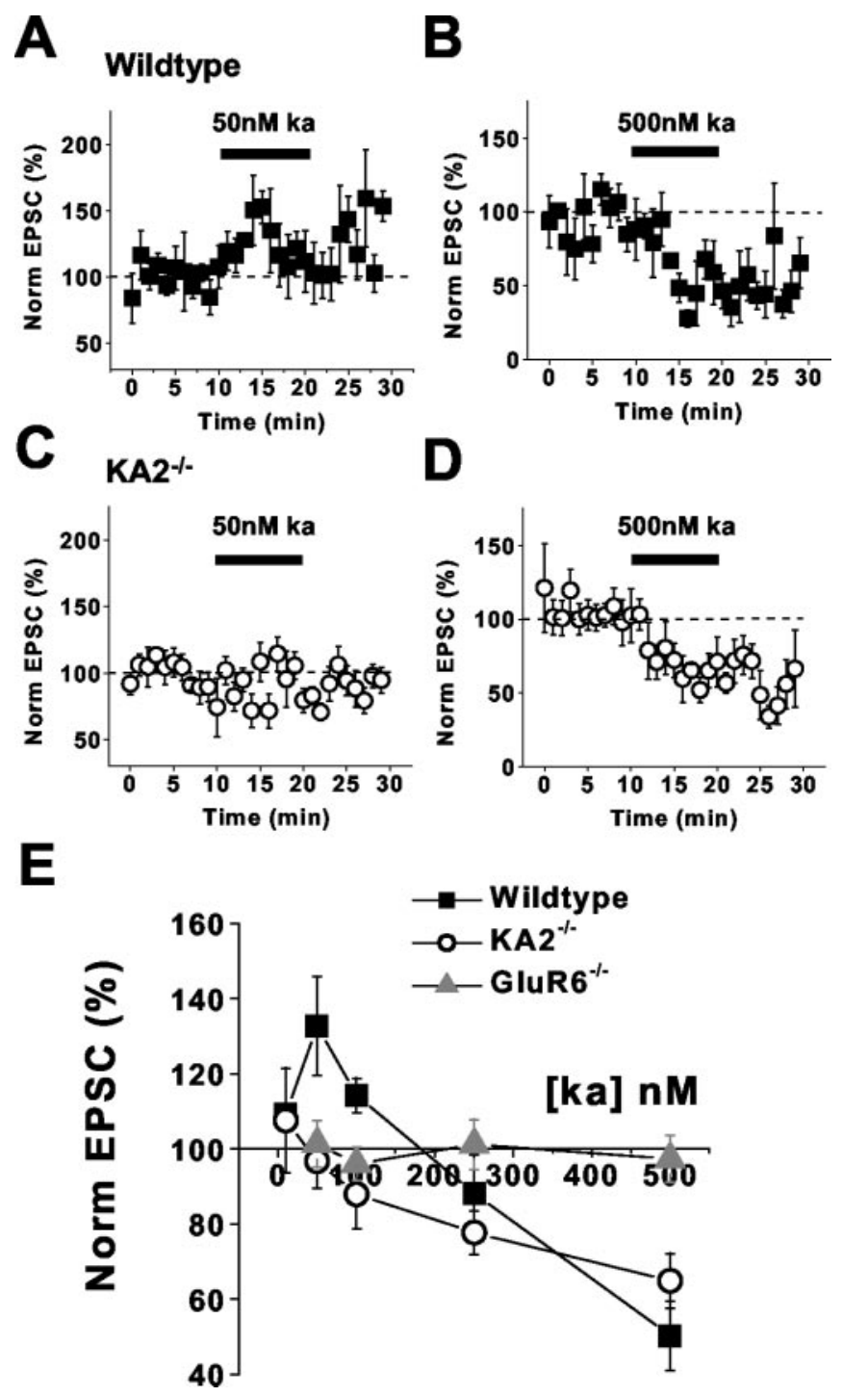

Figure 2. Facilitation of mossy-fiber EPSCs by low kainate concentrations is absent in $\mathrm{KA}^{-1-}$ mice. $A$, Application of $50 \mathrm{~nm}$ kainate to hippocampal slices from wild-type mice potentiates mossy-fiber EPSCs. $B$, Application of $500 \mathrm{~nm}$ kainate to slices from wild-type mice depresses mossy-fiber EPSCS. C, Mossy-fiber EPSC facilitation is not observed when 50 nм kainate is applied to slices from KA2 ${ }^{-1-}$ mice. D, Depression of mossy-fiber synaptic transmission is still observed in $\mathrm{KA2}^{-1-}$ mice with $500 \mathrm{~nm}$ kainate application. $E$, Summary of kainatemediated effects in wild-type, $\mathrm{KA}^{-1-}$, and $\mathrm{GluR6}{ }^{-1-}$ mice.

These results suggested that the agonist affinity of the presynaptic kainate receptors in the $\mathrm{KA} 2^{-1-}$ mice had shifted to higher concentrations. Alternatively, it was possible that the receptors had a higher agonist affinity, and that the transition from potentiation to inhibition was shifted to very low concentrations in the $\mathrm{KA} 2^{-1-}$ mice. Therefore, we tested the effect of a lower concentration of kainate on mossy-fiber transmission. The application of 10 nm kainate to slices did not affect mossy-fiber EPSC amplitudes in recordings from either wild-type or KA2 ${ }^{-1-}$ mice (wild type, $110 \pm 3.0, n=3, p>0.05 ; \mathrm{KA}^{-l-}, 110 \pm 14, n=3, p>$ 0.05 ; one-way ANOVA).

Short-term plasticity is not impaired in $\mathrm{KA}^{-1-}$ mice Our initial results suggested that $\mathrm{KA} 2^{-/-}$mice had presynaptic mossy-fiber kainate receptors with reduced sensitivity to activation by agonist. To test whether the alteration in presynaptic receptors similarly reduced their contribution to the facilitation
A Wildtype

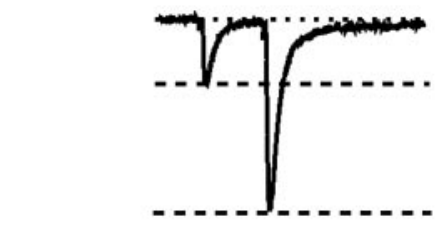

KA2-1-

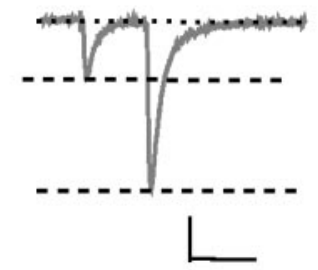

Wildtype

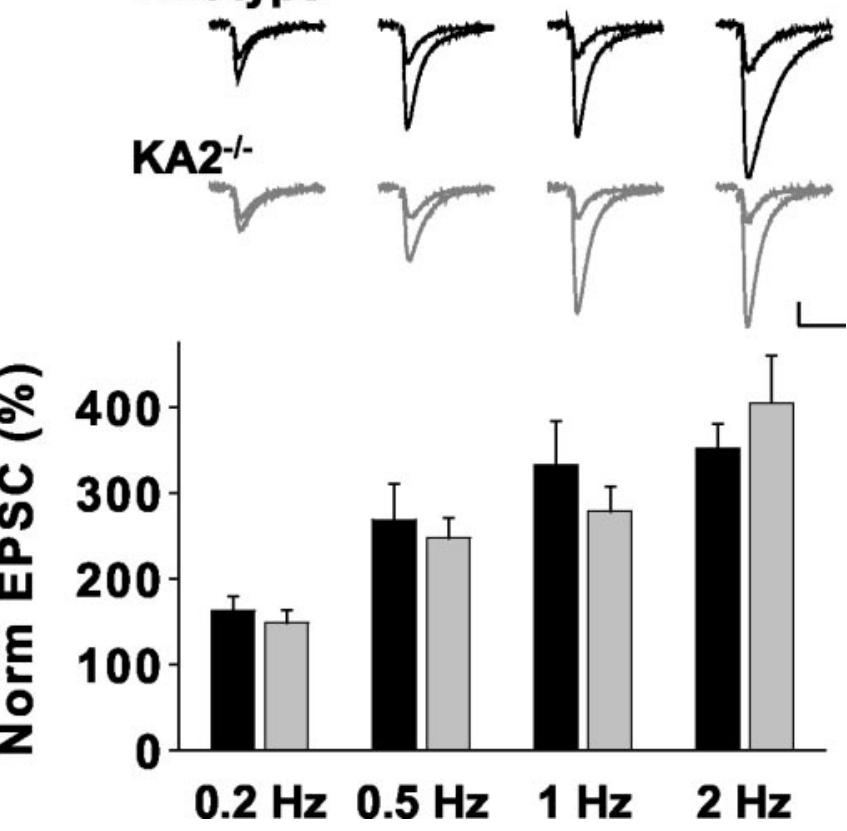

Figure 3. Mossy-fiber short-term plasticity is normal in $\mathrm{KA2}^{-/-}$mice. A, Sample traces of mossy-fiber EPSCs paired at $40 \mathrm{msec}$ intervals in wild-type mice (left) and KA2 ${ }^{-1-}$ mice (right). Calibration: $40 \mathrm{msec}, 300 \mathrm{pA}$. B, Top, Sample mossy-fiber EPSCs showing facilitation at frequencies of $0.2,0.5,1$, and $2 \mathrm{~Hz}$ in wild-type and $\mathrm{KA2}^{-1-}$ mice. Calibration: $20 \mathrm{msec}, 200 \mathrm{pA}$. Bottom, Summary of frequency facilitation experiments in wild-type (black bars) and $\mathrm{KA}^{-1-}$ ( gray bars) mice.

of transmission at mossy-fiber synapses, we compared two forms of short-term plasticity in wild-type and knock-out mice (Contractor et al., 2001). In recordings from $\mathrm{KA}^{-1-}$ mice, pairedpulse ratios of $\mathrm{EPSC}_{\mathrm{AMPA} / \mathrm{KA}}$ measured at an interstimulus interval of $40 \mathrm{msec}$ were normal compared with wild-type mice (wild type, $\left.2.9 \pm 0.17, n=15 ; \mathrm{KA}^{-l-}, 3.0 \pm 0.17, n=19 ; p>0.05\right)$ (Fig. 3A). We also tested frequency facilitation of mossy fibers by increasing the stimulation frequency to four different rates from a base of $0.05 \mathrm{~Hz}$. Frequency facilitation was not significantly different between wild-type and $\mathrm{KA} 2^{-1-}$ slices at frequencies of $0.2 \mathrm{~Hz}$ (wild type, $n=7$; KA2 ${ }^{-\prime-}, n=10 ; p>0.05$ ), $0.5 \mathrm{~Hz}$ (wild type, $n=7$; KA2 ${ }^{-l-}, n=10 ; p>0.05$ ), $1 \mathrm{~Hz}$ (wild type, $n=7$; $\mathrm{KA}^{-l-}, n=10 ; p>0.05$ ), or $2 \mathrm{~Hz}$ (wild type, $n=7$; KA2 ${ }^{-l-}$, $n=4 ; p>0.05$ ) (Fig. 3B). These results suggest that homosynaptic activation of the facilitatory autoreceptor is normal in the knock-out mice, despite the absence of the KA2 subunit.

Faster decay kinetics of the $\mathrm{EPSC}_{\mathrm{KA}}$ in $\mathrm{KA}^{-1-}$ mice We recorded kainate receptor-mediated EPSCs from CA3 neurons to test whether deletion of the KA2 subunit alters the properties of postsynaptic receptors. EPSC $_{\mathrm{KA}}$ were isolated from $\mathrm{EPSC}_{\mathrm{AMPA}}$ by applying a noncompetitive AMPA receptor antagonist, GYKI53655 
A

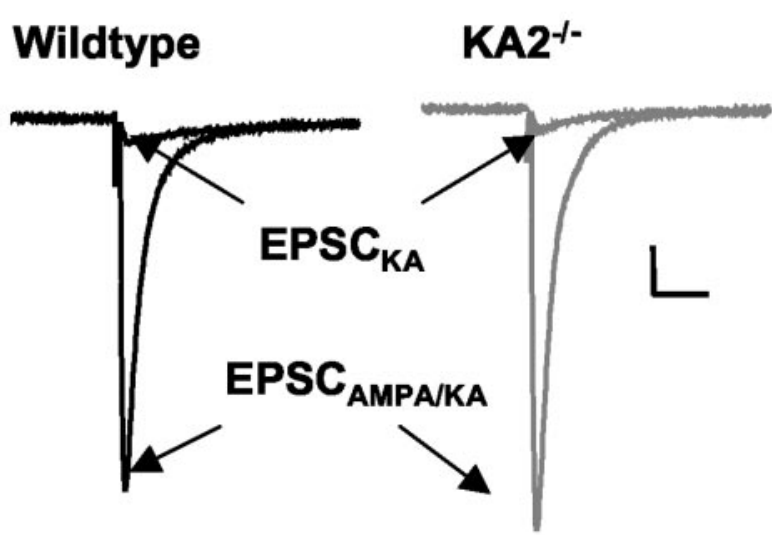

B

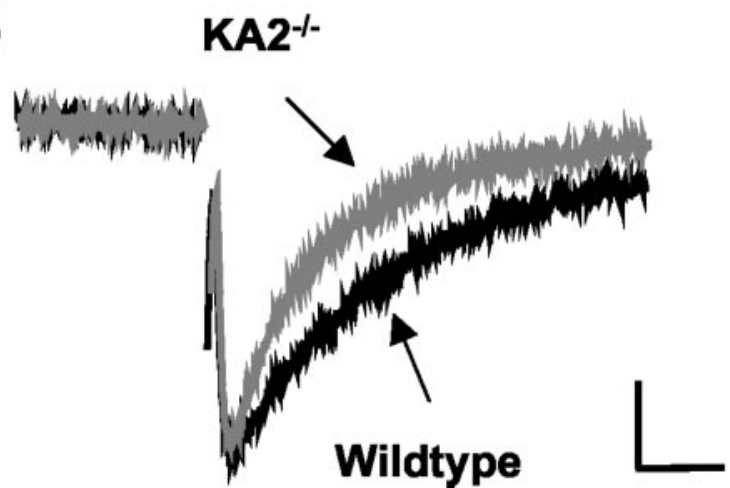

Figure 4. Decay of the kainate component of the PSC is faster in $\mathrm{KA2}^{-1-}$ mice. $A$, Sample mossy-fiber EPSCS showing the mixed AMPA/kainate EPSC and the isolated EPSC $\mathrm{KA}_{\mathrm{KA}}$ recorded at $1 \mathrm{~Hz}$ stimulation frequency in slices from wild-type and $\mathrm{KA}^{-1-}$ mice. Calibration: $20 \mathrm{msec}$,

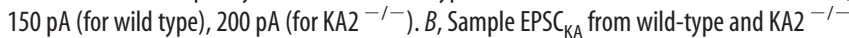
mice. Calibration: $20 \mathrm{msec}, 20 \mathrm{pA}$ (for wild-type), $25 \mathrm{pA}$ (for $\mathrm{KA}^{-/-}$).

(100 $\mu \mathrm{M})$, and increasing the release probability by stimulating mossy-fiber afferents at $1 \mathrm{~Hz}$. Under these conditions, the proportion of the mossy-fiber EPSC mediated by kainate receptors was not significantly altered in the KA2 ${ }^{-1-}$ mice (wild type, $6.7 \pm 0.4 \%, n=$ 9; $\mathrm{KA}^{-1-}, 6.8 \pm 0.9 \%, n=7 ; p>0.05$ ) (Fig. $4 A$ ). However, the $\mathrm{EPSC}_{\mathrm{KA}}$ in $\mathrm{KA}^{-1-}$ mice decayed significantly faster than those in wild-type mice (wild type, $64 \pm 2.5 \mathrm{msec}, n=10$; $\mathrm{KA}^{-/-}, 41 \pm 3.3$ msec, $n=7 ; p<0.001$ ) (Fig. $4 B$ ). These results demonstrate that postsynaptic kainate receptors are composed of heteromers of at least the KA2 and GluR6 subunits, and that the KA2 is not critical for the functional expression of synaptic kainate receptors.

\section{Spillover-mediated heterosynaptic facilitation is absent in} $\mathrm{KA}^{-1-}$ mice

The high-affinity facilitatory presynaptic kainate receptor can be activated by the spillover of glutamate from neighboring collateral synapses on CA3 pyramidal neurons (Schmitz et al., 2001a). To test whether this heterosynaptic facilitation is altered in $\mathrm{KA} 2^{-1-}$ mice, we made recordings from CA3 neurons while simultaneously stimulating two synaptic pathways. In the first set

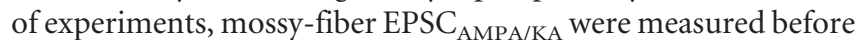
and $100 \mathrm{msec}$ after brief conditioning stimuli were delivered to collateral pathways (three stimuli at $200 \mathrm{~Hz}$ ). This stimulation protocol has been shown previously to give a robust facilitation of mossy-fiber EPSCs (Schmitz et al., 2001a); in agreement with this, we saw a facilitation of mossy-fiber EPSC in five of seven
A

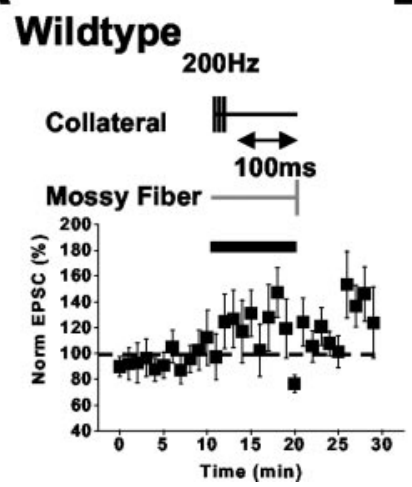

B

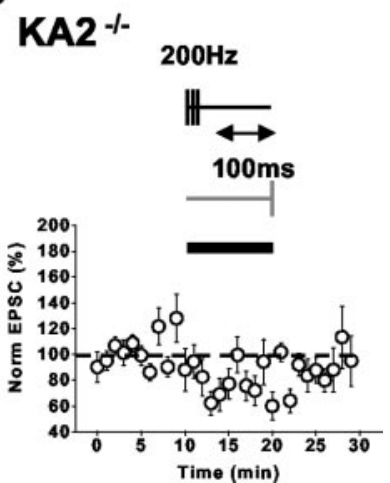

Figure 5. Spillover-mediated heterosynaptic facilitation is not observed in $\mathrm{KA}^{-1-}$ mice. $A$, Normalized mossy-fiber EPSC amplitudes in wild-type mice. During the time denoted by the black bar, mossy-fiber stimulation is preceded for $100 \mathrm{msec}$ by three high-frequency stimuli to collateral synapses in the stratum radiatum. $B$, The effect of the same collateral conditioning stimulation on mossy-fiber EPSCs in slices from $\mathrm{KA2}^{-1-}$ mice.
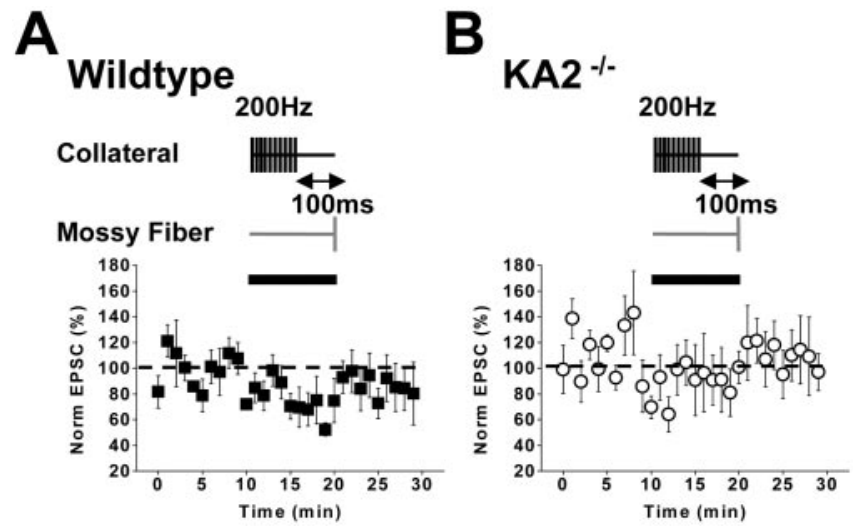

Figure 6. High-frequency induced heterosynaptic depression is observed in $\mathrm{KA}^{-/-}$mice. A, Normalized mossy-fiber EPSCs in wild-type mice. During the time denoted by the black bar, mossy-fiber stimulation was preceded for $100 \mathrm{msec}$ by 10 stimuli at $200 \mathrm{~Hz}$ frequency given to collateral synapses in the stratum radiatum. $B$, The same collateral conditioning experiment in slices from $\mathrm{KA2}^{-1-}$ mice.

recordings from wild-type mice (normalized potentiation for all wild-type recordings, $120 \pm 15 \% ; n=7 ; p<0.05$; one-way ANOVA) (Fig. 5A). However, this spillover-mediated facilitation was absent in recordings from the $\mathrm{KA} 2^{-1-}$ mice; instead, we observed a significant depression of the mossy-fiber EPSC (79 \pm $5.6 \%$ of control EPSC; $n=10 ; p<0.05$; one-way ANOVA) (Fig. $5 B$ ). We also made recordings in which the mossy-fiber test pulse was given after longer trains of high-frequency stimulation (10 stimuli at $200 \mathrm{~Hz}$ ), which was designed to activate axonal kainate receptors maximally and thereby cause a depression of transmission (Schmitz et al., 2001a). In both wild-type and KA2 ${ }^{-1-}$ mice, this protocol significantly depressed the mossy-fiber EPSC (wild type, $79 \pm 5.9, n=6, p<0.05 ; \mathrm{KA}^{-1-}, 76 \pm 7.8 \%, n=7, p<$ 0.05; one-way ANOVA) (Fig. $6 A, B$ ). Therefore, heterosynaptic facilitation of the mossy-fiber pathway is impaired in $\mathrm{KA} 2^{-1-}$ mice, whereas glutamate spillover can still activate axonal kainate receptors and depress mossy-fiber synaptic transmission. These results parallel those observed with the exogenous application of kainate.

Mossy-fiber long-term plasticity is normal in $\mathrm{KA}^{-/-}$mice Multiple forms of NMDA-independent long-term synaptic plasticity exist at mossy-fiber synapses (Yeckel et al., 1999). One form 
A
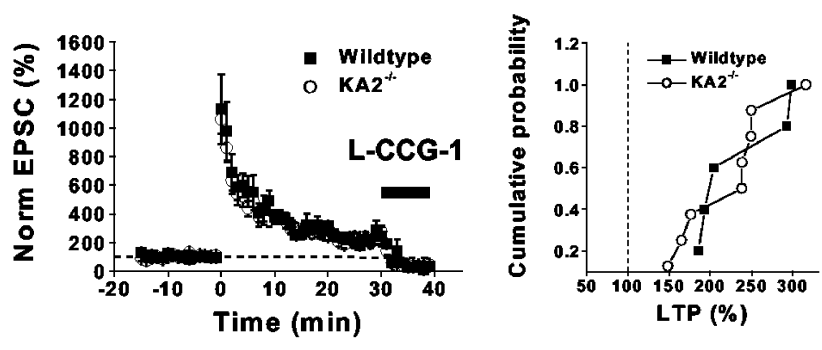

C
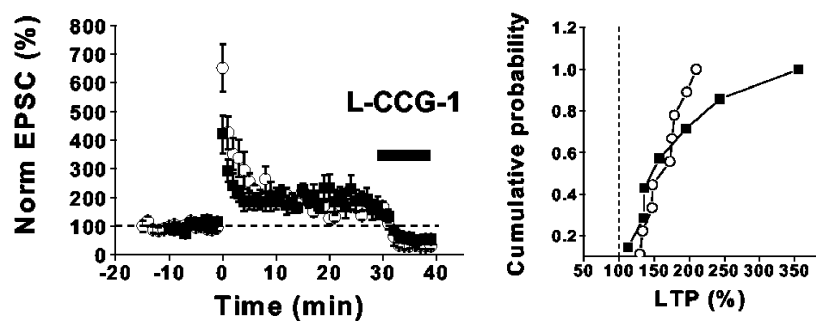

Figure 7. Mossy-fiber LTP is normal in $\mathrm{KA} 2^{-1-}$ mice. $A$, Time course of mossy-fiber LTP in wild-type and $\mathrm{KA2}^{-1-}$ mice induced by tetanic stimulation $(31 \mathrm{sec}$ trains of $100 \mathrm{~Hz}$ stimulation). Inhibition of the EPSC by the group II mGluR agonist L-CCG-1 at the end of each experiment was used to confirm that the EPSCs were of mossy-fiber origin (Kamiya et al., 1996). B, Cumulative probability histogram of tetanus induced LTP in wild-type and $\mathrm{KA} 2^{-1-}$ mice. $C$, Time course of mossy-fiber LTP in wild-type and $\mathrm{KA}^{-1-}$ mice induced by BHFS (15 trains of 7 stimuli at $100 \mathrm{~Hz}$ frequency at $5 \mathrm{sec}$ intervals). D, Cumulative probability histogram of BHFSinduced LTP in wild-type and $K A 2^{-1-}$ mice.

of long-term potentiation (LTP) requires the activation of kainate receptors for induction (Bortolotto et al., 1999; Contractor et al., 2001). We tested whether mossy-fiber LTP was impaired in the $\mathrm{KA}^{-1-}$ mice, as it is in the GluR6 ${ }^{-1-}$ mice (Contractor et al., 2001). Two induction protocols were used to differentiate between distinct forms of mossy-fiber LTP (Urban and Barrionuevo, 1996; Yeckel et al., 1999). In the first set of experiments, we induced LTP using a standard tetanus consisting of three $1 \mathrm{sec}$ trains of $100 \mathrm{~Hz}$ stimulation given at $10 \mathrm{sec}$ intervals. There was no difference in the magnitude of facilitation measured 20-30 min after the induction between wild-type and knock-out mice [wild type, $230 \pm 25 \%, n=5$; KA2 ${ }^{-l-}$, $220 \pm 20 \%, n=8 ; p>$ 0.05; Kolmogorov-Smirnov (K-S) test] (Fig. 7A, B). A less intense induction protocol (15 trains of seven stimuli at $100 \mathrm{~Hz}$ frequency at $5 \mathrm{sec}$ intervals), termed brief high frequency stimulation (BHFS) (Urban and Barrionuevo, 1996), elicited LTP that was similar in magnitude in wild-type and $\mathrm{KA} 2^{-1-}$ mutant mice (wild type, $190 \pm 32 \%, n=7 ; \mathrm{KA} 2^{-l-}, 170 \pm 9 \%, n=9 ; p>0.5$; $\mathrm{K}-\mathrm{S}$ test) (Fig. 7C,D). Therefore, plasticity of the mossy-fiber synapse is impaired only when the functional synaptic kainate receptors are absent (in the GluR6 $6^{-1-}$ mice) but is normal in mice in which the kainate receptors have more subtle alterations in function, like the $\mathrm{KA} 2^{-1-}$ mice.

\section{Discussion}

The development of kainate receptor knock-out mice has helped elucidate the roles of these glutamate-gated ion channels in the brain. Here we report the generation and physiological characterization of a mouse in which the KA2 receptor subunit is deleted. We found that presynaptic and postsynaptic kainate receptor function at hippocampal mossy-fiber-CA3 pyramidal cell synapses is altered but not eliminated in these mice. These data lead us to conclude that neuronal kainate receptors at mossyfiber synapses contain the KA2 subunit, and that this subunit influences the biophysical properties of mossy-fiber kainate receptors. In particular, this subunit confers a higher glutamate affinity on the presynaptic receptor on the mossy-fiber terminals. KA2-subunit-containing receptors are activated by low concentrations of glutamate that spill over from adjacent collateral synapses, which modifies the strength of mossy-fiber transmission if coincident activation occurs within an appropriate time window.

\section{Presynaptic mossy-fiber kainate receptors}

Presynaptic kainate receptors modulate excitatory (Contractor et al., 2000; Kamiya and Ozawa, 2000; Schmitz et al., 2000; Frerking et al., 2001; Delaney and Jahr, 2002; Kidd et al., 2002) and inhibitory (Rodriguez-Moreno et al., 1997, 2000; Min et al., 1999; Mulle et al., 2000) transmission at a number of central synapses, including the hippocampal mossy-fiber synapse. Kainate receptors are expressed at high levels in this region of the brain, and this synapse has been used as a model for studying their function. Initial studies of presynaptic receptors at mossy-fiber synapses reported that the activation of kainate receptors depressed excitatory transmission at these synapses because of a depolarizing block of action potential conductance (Kamiya and Ozawa, 2000; Schmitz et al., 2000). Studies in knock-out mice confirmed that this depression of the EPSC was mediated by kainate receptors composed of the GluR6 subunit (Contractor et al., 2000).

Subsequent studies found that the activation of kainate receptors with low concentrations of kainate facilitated mossy-fiber transmission (Schmitz et al., 2001a). Both facilitation and depression of mossy-fiber transmission by exogenous kainate can be reproduced by activating presynaptic kainate receptors with synaptically released glutamate, suggesting that these receptors represent a functional modulatory system in vivo (Schmitz et al., 2000, 2001a). The biphasic effect of the activation of presynaptic kainate receptors is thought to result from the differential excitation of mossy fibers. Moderate kainate receptor activation inactivates repolarizing potassium channels and thereby increases mossy-fiber excitability. More profound kainate receptor activation elicits a larger depolarization that inactivates sodium channels, resulting in a depolarizing block of action potential conduction (Schmitz et al., 2001b). The high affinity of the presynaptic receptor for glutamate is a crucial element in this form of heterosynaptic modulation of mossy-fiber transmission. In the present study, we found heterosynaptic depression to be normal in $\mathrm{KA} 2^{-1-}$ mice, whereas heterosynaptic facilitation was absent. Therefore, the KA2 receptor subunit is critical to this physiological function, because it confers high affinity for glutamate on the presynaptic receptors.

Presynaptic kainate receptors also have an autoreceptor function at mossy-fiber synapses. Glutamate released from mossyfiber terminals can activate presynaptic kainate receptors and facilitate subsequent release (Contractor et al., 2001; Lauri et al., 2001). This autoreceptor function becomes critical in facilitating mossy-fiber transmission during periods of high-frequency transmission. GluR6 ${ }^{-1-}$ mice have impairments in frequency facilitation of mossy-fiber transmission, suggesting that GluR6 is critical for this autoreceptor function (Contractor et al., 2001). In the present study, we found that this form of synaptic plasticity was intact in $\mathrm{KA}^{-1-}$ mice. It is likely that the glutamate concentrations involved in homosynaptic facilitation are higher than those associated with spillover-mediated activation of presynaptic kainate receptors; therefore, alteration in the affinity of pre- 
synaptic receptors in $\mathrm{KA} 2^{-1-}$ mice has no effect on this autoreceptor function.

\section{Postsynaptic mossy-fiber kainate receptors}

Kainate receptors are also located on the postsynaptic side of mossy-fiber synapses. Initial studies that isolated the kainate receptor component of the mossy-fiber EPSC used trains of highfrequency stimulation to increase the probability of release and to resolve the EPSC $_{\mathrm{KA}}$ clearly (Castillo et al., 1997; Vignes and Collingridge, 1997). These observations suggested that kainate receptors might not participate in ongoing transmission at mossy fibers but rather might be activated only during periods of significantly increased mossy-fiber activity. Although EPSC $_{\mathrm{KA}}$ are more readily observed when mossy-fiber release probability is increased, a recent study has shown that, as at thalamocortical synapses (Kidd and Isaac, 1999), mossy-fiber kainate receptors are activated by the quantal release of glutamate and thus are intrinsic to the excitatory synaptic transmission of mossy fibers (Cossart et al., 2002). In addition, although the amplitude of the $\mathrm{EPSC}_{\mathrm{KA}}$ is small relative to $\mathrm{EPSC}_{\mathrm{AMPA}}$, the slow decay kinetics of the $\mathrm{EPSC}_{\mathrm{KA}}$ causes a significant proportion of the total charge to be transferred through kainate receptors during the composite mossy-fiber EPSC. The evidence that kainate receptors are activated by the quantal release of glutamate at mossy-fiber synapses (Cossart et al., 2002) as well as previous demonstrations that the manipulation of glutamate clearance from the synaptic cleft did not affect the kinetics of the EPSC $_{\mathrm{KA}}$ (Castillo et al., 1997; Vignes and Collingridge, 1997) strongly support the hypothesis that the slow kinetics of the $\mathrm{EPSC}_{\mathrm{KA}}$ results from the intrinsic properties of the receptors rather than localization to extrasynaptic or perisynaptic sites. Our data also support this idea, because we find that the time course of the EPSC $\mathrm{KA}$ is markedly more rapid when the KA2 subunit is absent from the postsynaptic receptor complex. In addition, these data are generally consistent with the idea that the KA2 subunit confers a very high affinity for glutamate on mossy-fiber kainate receptors and thereby contributes to the relatively slow decay of the EPSC $_{\mathrm{KA}}$. It remains to be determined what other mechanisms are responsible for the disparity in the properties between mossy-fiber EPSC $_{\mathrm{KA}}$ and those predicted from the studies of recombinant receptors.

The EPSC $_{\mathrm{KA}}$ was absent when the GluR6 receptor subunit was deleted (Mulle et al., 1998) but normal in GluR5 ${ }^{-1-}$ mice (Contractor, unpublished observations), suggesting that the GluR6 subunit is critical for the functional expression of postsynaptic kainate receptors. The application of an antagonist selective for GluR5-containing receptors, LY382884, reduced mossy-fiber EPSC $_{\mathrm{KA}}$, initially suggesting that the postsynaptic receptor contained the GluR5 subunit (Bortolotto et al., 1999). However, a second report demonstrated that the antagonist LY382884 did not depress the $\mathrm{EPSC}_{\mathrm{KA}}$ directly, but rather acted on presynaptic kainate receptors to reduce frequency facilitation and thereby indirectly to reduce the $\mathrm{EPSC}_{\mathrm{KA}}$ evoked with high-frequency stimulation trains (Lauri et al., 2001); furthermore, this compound did not act on the postsynaptic receptor. Together with mRNA expression patterns (Bahn et al., 1994; Bureau et al., 1999), these data suggest that the postsynaptic kainate receptor is composed of heteromers of GluR6 and KA2, although the KA1 receptor subunit might also be present.

\section{Kainate receptor involvement in mossy-fiber LTP}

Mossy-fiber LTP is mechanistically distinct from the more commonly studied NMDA receptor-dependent forms of plasticity (Henze et al., 2000). Kainate receptors play an integral role in the induction of mossy-fiber LTP. A selective antagonist of kainate receptors (Bortolotto et al., 1999) and genetic deletion of the GluR6 subunit (Contractor et al., 2001) both impair LTP induction at this synapse. Because kainate receptors are localized to both presynaptic and postsynaptic sides of the synapse, it is not clear which of these receptor populations is involved in the induction of plasticity. However, recent reports that postsynaptic mechanisms are required for the induction of this form of synaptic plasticity (Yeckel et al., 1999; Contractor et al., 2002) raise the intriguing possibility that the $\mathrm{EPSC}_{\mathrm{KA}}$ might mediate the induction of LTP. In this study, we have found that, although both presynaptic and postsynaptic kainate receptor function are perturbed in $\mathrm{KA}^{-I-}$ mice, mossy-fiber LTP is normal.

\section{References}

Bahn S, Volk B, Wisden W (1994) Kainate receptor gene expression in the developing rat brain. J Neurosci 14:5525-5547.

Bortolotto ZA, Clarke VRJ, Delany CM, Parry MC, Smolders I, Vignes M, Ho KH, Miu P, Brinton BT, Fantaske R, Ogden A, Gates M, Ornstein PL, Lodge D, Bleakman D, Collingridge GL (1999) Kainate receptors are involved in synaptic plasticity. Nature 402:297-301.

Bureau I, Bischoff S, Heinemann SF, Mulle C (1999) Kainate receptormediated responses in the CA1 field of wild-type and GluR6-deficient mice. J Neurosci 19:653-663.

Castillo PE, Malenka RC, Nicoll RA (1997) Kainate receptors mediate a slow postsynaptic current in hippocampal CA3 neurons. Nature 388:182-186.

Contractor A, Swanson GT, Sailer A, O'Gorman S, Heinemann SF (2000) Identification of the kainate receptor subunits underlying modulation of excitatory synaptic transmission in the CA3 region of the hippocampus. J Neurosci 20:8269-8278.

Contractor A, Swanson G, Heinemann SF (2001) Kainate receptors are involved in short- and long-term plasticity at mossy-fiber synapses in the hippocampus. Neuron 29:209-216.

Contractor A, Rogers C, Maron C, Henkemeyer M, Swanson GT, Heinemann SF (2002) Trans-synaptic Eph receptor-ephrin signaling in hippocampal mossy-fiber LTP. Science 296:1864-1869.

Cossart R, Epstein J, Tyzio R, Becq H, Hirsch J, Ben-Ari Y, Crepel V (2002) Quantal release of glutamate generates pure kainate and mixed AMPA/ kainate EPSCs in hippocampal neurons. Neuron 35:147-159.

Delaney AJ, Jahr CE (2002) Kainate receptors differentially regulate release at two parallel fiber synapses. Neuron 36:475-482.

Dingledine R, Borges K, Bowie D, Traynelis SF (1999) The glutamate receptor ion channels. Pharmacol Rev 51:7-61.

Frerking M, Schmitz D, Zhou Q, Johansen J, Nicoll RA (2001) Kainate receptors depress excitatory synaptic transmission at CA3 $\rightarrow$ CA1 synapses in the hippocampus via a direct presynaptic action. J Neurosci 21:2958-2966.

Henze DA, Urban NN, Barrionuevo G (2000) The multifarious hippocampal mossy-fiber pathway: a review. Neuroscience 98:407-427.

Herb A, Burnashev N, Werner P, Sakmann B, Wisden W, Seeburg PH (1992) The KA-2 subunit of excitatory amino acid receptors shows widespread expression in brain and forms ion channels with distantly related subunits. Neuron 8:775-785.

Kamiya H, Ozawa S (2000) Kainate receptor-mediated presynaptic inhibition at the mouse hippocampal mossy-fiber synapse. J Physiol (Lond) 523:653-665.

Kamiya H, Shinozaki H, Yamamoto C (1996) Activation of metabotropic glutamate receptor type 2/3 suppresses transmission at rat hippocampal mossy-fiber synapses. J Physiol (Lond) 493:447-455.

Kidd FL, Isaac JT (1999) Developmental and activity-dependent regulation of kainate receptors at thalamocortical synapses. Nature 400:569-573.

Kidd FL, Coumis U, Collingridge GL, Crabtree JW, Isaac JT (2002) A presynaptic kainate receptor is involved in regulating the dynamic properties of thalamocortical synapses during development. Neuron 34:635-646.

Kullmann DM (2001) Presynaptic kainate receptors in the hippocampus: slowly emerging from obscurity. Neuron 32:561-564.

Laird PW, Zijderveld A, Linders K, Rudnicki MA, Jaenisch R, Berns A (1991) Simplified mammalian DNA isolation procedure. Nucleic Acids Res 19:4293.

Lauri SE, Bortolotto ZA, Bleakman D, Ornstein PL, Lodge D, Isaac JT, Col- 
lingridge GL (2001) A critical role of a facilitatory presynaptic kainate receptor in mossy-fiber LTP. Neuron 32:697-709.

Lomeli H, Wisden W, Kohler M, Keinanen K, Sommer B, Seeburg PH (1992) High-affinity kainate and domoate receptors in rat brain. FEBS Lett 307:139-143.

Mansour SL, Thomas KR, Capecchi MR (1988) Disruption of the protooncogene int- 2 in mouse embryo-derived stem cells: a general strategy for targeting mutations to non-selectable genes. Nature 336:348-352.

Min MY, Melyan Z, Kullmann DM (1999) Synaptically released glutamate reduces $\gamma$-aminobutyric acid (GABA)ergic inhibition in the hippocampus via kainate receptors. Proc Natl Acad Sci USA 96:9932-9937.

Mulle C, Sailer A, Pérez-Otano I, Dickinson-Anson H, Castillo PE, Bureau I, Maron C, Gage FH, Mann JR, Bettler B, Heinemann SF (1998) Altered synaptic physiology and reduced susceptibility to kainate-induced seizures in GluR6-deficient mice. Nature 392:601-605.

Mulle C, Sailer A, Swanson GT, Brana C, O’Gorman S, Bettler B, Heinemann SF (2000) Subunit composition of kainate receptors in hippocampal interneurons. Neuron 28:475-484.

Petralia RS, Wang YX, Wenthold RJ (1994) Histological and ultrastructural localization of the kainate receptor subunits, KA2 and GluR6/7, in the rat nervous system using selective antipeptide antibodies. J Comp Neurol 349:85-110.

Rodriguez-Moreno A, Herreras O, Lerma J (1997) Kainate receptors presynaptically downregulate GABAergic inhibition in the rat hippocampus. Neuron 19:893-901.

Rodriguez-Moreno A, Lopez-Garcia JC, Lerma J (2000) Two populations of kainate receptors with separate signaling mechanisms in hippocampal interneurons. Proc Natl Acad Sci USA 97:1293-1298.
Sailer A, Swanson GT, Perez-Otano I, O’Leary L, Malkmus SA, Dyck RH, Dickinson-Anson $\mathrm{H}$, Schiffer $\mathrm{HH}$, Maron C, Yaksh TL, Gage FH, O'Gorman S, Heinemann SF (1999) Generation and analysis of GluR5(Q636R) kainate receptor mutant mice. J Neurosci 19:8757-8764.

Salin PA, Scanziani M, Malenka RC, Nicoll RA (1996) Distinct short-term plasticity at two excitatory synapses in the hippocampus. Proc Natl Acad Sci USA 93:13304-13309.

Schiffer HH, Swanson GT, Heinemann SF (1997) Rat GluR7 and a carboxyterminal splice variant, GluR7b, are functional kainate receptor subunits with a low sensitivity to glutamate. Neuron 19:1141-1146.

Schmitz D, Frerking M, Nicoll RA (2000) Synaptic activation of presynaptic kainate receptors on hippocampal mossy-fiber synapses. Neuron 27:327-338.

Schmitz D, Mellor J, Nicoll RA (2001a) Presynaptic kainate receptor mediation of frequency facilitation at hippocampal mossy-fiber synapses. Science 291:1972-1976.

Schmitz D, Mellor J, Frerking M, Nicoll RA (2001b) Presynaptic kainate receptors at hippocampal mossy-fiber synapses. Proc Natl Acad Sci USA 98:11003-11008.

Urban NN, Barrionuevo G (1996) Induction of Hebbian and non-Hebbian mossy-fiber long-term potentiation by distinct patterns of highfrequency stimulation. J Neurosci 16:4293-4299.

Vignes M, Collingridge GL (1997) The synaptic activation of kainate receptors. Nature 388:179-182.

Yeckel MF, Kapur A, Johnston D (1999) Multiple forms of LTP in hippocampal CA3 neurons use a common postsynaptic mechanism. Nat Neurosci 2:625-633. 